\title{
Detection of Newcastle disease virus of poultry by real time reverse transcription-polymerase chain reaction
}

\author{
MM Rahman, LR Barman, EH Chowdhury and MR Islam* \\ Department of Pathology, Faculty of Veterinary Science, Bangladesh Agricultural \\ University, Mymensingh-2202, Bangladesh
}

\begin{abstract}
A real-time reverse transcription - polymerase chain reaction (rRT-PCR) was used for the detection of Newcastle disease virus (NDV) of poultry. A panel of seven known isolates of NDV in the form of allantoic fluid, obtained from a laboratory repository, was used for the development of the test. RNA was extracted from the allantoic fluid with a magnetic processor based automated RNA extraction system. The identity of the reference virus was first reconfirmed by a conventional RT-PCR specific for the Fusion (F) protein gene. Using these RNA, the rRT-PCR protocol was optimized with regard to the reaction mix and thermal profile using published primers and probes specific for $\mathrm{M}$ gene. The sensitivity of standardized rRT-PCR was compared to that of the conventional RT-PCR using serial 10-fold dilutions of the RNA of a selected sample. The thermal profile was modified from the published one; the annealing and extension steps were combined to a single step performed at $60^{\circ} \mathrm{C}$. The adopted rRT-PCR successfully amplified M gene from all the seven reference samples with a $\mathrm{C}_{\mathrm{T}}$ value ranging from 15.28 to 32.68 . The rRT-PCR for $\mathrm{M}$ gene was 100-fold more sensitive than the conventional RT-PCR for F gene. This is the first report of the use of rRT-PCR for the detection of NDV in Bangladesh. This test will be useful for virological surveillance, particularly for screening NDV in respiratory infections. (Bangl. vet. 2016. Vol. 33, No. 1, 16 - 22)
\end{abstract}

\section{Introduction}

Newcastle disease (ND) or Ranikhet disease is an economically important disease of poultry in Bangladesh. Newcastle disease virus (NDV), also known as virulent forms of Avian Paramyxovirus serotype 1 (APMV-1), is a single-stranded, negative-sense RNA virus within the genus of Avulavirus in the family Paramyxoviridae (Lamb et al., 2005). Isolation of NDV in embryonated chicken eggs and their identification by haemagglutination (HA) and haemagglutination inhibition (HI) test with a NDVmonospecific antiserum is the gold standard for the detection of NDV (OIE, 2012), but the procedure is time-consuming. Reverse transcription-polymerase chain reaction (RT-PCR) has been established to identify NDV (Jestin and Jestin, 1991; Kho et al., 2000, Zhang et al., 2010). Real time RT-PCR (rRT-PCR) is more sensitive and quicker, and has recently been used for the identification and typing of NDV (Wise et al., 2004; Tan et al., 2004; Pham et al., 2005; Farkas et al., 2009; Khan et al., 2010; Qiu et al., 2014).

${ }^{*}$ Corresponding author:- E-mail: mrislam_bau@yahoo.com 
Previous research on NDV in Bangladesh has focused on isolation, characterization and pathogenicity testing (Chowdhury et al., 1981; Saha et al., 1997; Noor et al., 2005; Barman et al., 2010; Mazumder et al., 2012) and use of conventional RT-PCR for the detection of the virus (Islam et al., 2010; Khan et al., 2014; Nooruzzaman et al., 2015). The present study aimed at the adoption of an rRT-PCR technique for the detection of Newcastle disease virus.

\section{Materials and Methods}

Virus isolates

A total of seven known isolates of NDV, previously detected by RT-PCR and propagated in embryonated chicken eggs, were obtained in allantoic fluid from a previous study (Barman, 2016).

\section{Primers and probes}

The details of the primers and probes used in the conventional RT-PCR and rRT-PCR are given in Table 1 . The primers and probe were synthesized from a commercial source (Integreted DNA Technologies, Inc., USA).

Table 1. Primers and probes used in conventional RT-PCR and rRT-PCR for the detection of NDV

\begin{tabular}{|c|c|c|c|c|}
\hline $\begin{array}{l}\text { RT-PCR } \\
\text { format }\end{array}$ & $\begin{array}{l}\text { Primer name } \\
\text { (Reference) }\end{array}$ & Primer/probe sequence $\left(5^{\prime}-3^{\prime}\right)$ & $\begin{array}{l}\text { Target } \\
\text { gene }\end{array}$ & $\begin{array}{c}\text { Product } \\
\text { size }\end{array}$ \\
\hline \multirow{2}{*}{$\begin{array}{l}\text { Conven- } \\
\text { tional RT- } \\
\text { PCR }\end{array}$} & $\begin{array}{l}\text { P } 1 \\
\text { (Wang et al., 2006) }\end{array}$ & ATG GGC YCC AGA YCT TCT AC & F gene & $535 \mathrm{bp}$ \\
\hline & $\begin{array}{l}\text { P } 2 \\
\text { (Wang et al., 2006) }\end{array}$ & $\begin{array}{l}\text { CTG CCA CTG CTA GTT GTG ATA } \\
\text { ATC C }\end{array}$ & & \\
\hline \multirow[t]{3}{*}{$\begin{array}{l}\text { Real time } \\
\text { RT-PCR }\end{array}$} & $\begin{array}{l}\mathrm{M}+4100 \mathrm{~F} \\
\text { (Wise et al., 2004) }\end{array}$ & AGT GAT GTG CTC GGA CCT TC & M gene & $121 \mathrm{bp}$ \\
\hline & $\begin{array}{l}\text { M- } 4220 \mathrm{R} \\
\text { (Wise et al., 2004) }\end{array}$ & CCT GAG GAG AGG CAT TTG CTA & & \\
\hline & $\begin{array}{l}\text { NDVM + } 4169 \text { Probe } \\
\text { (Khan et al., 2010) } \\
\text { modified after (Wise } \\
\text { et al., 2004) }\end{array}$ & $\begin{array}{l}\text { [FAM] TTY TCT AGC AGY GGG ACA } \\
\text { GCY TGC [TAMRA] }\end{array}$ & & \\
\hline
\end{tabular}

Extraction of RNA, RT-PCR and rRT-PCR protocols

Viral RNA was extracted from infected allantoic fluid with King Fisher ML automated RNA extraction machine using Ambion MagMAXTM_96 Viral RNA Isolation Kit (Life Technologies, USA) following manufacturer's instructions. As the kit was designed for 96-well format, the volumes of reagents were adjusted for tube format of the RNA extraction machine. 
For amplification of the F gene fragment by conventional RT-PCR, SuperScript ${ }^{\circledR}$ III One-Step RT-PCR System with Platinum ${ }^{\circledR}$ Taq DNA polymerase (Life Technologies, USA) was used as recommended by the manufacturer. The thermal profile consisted of RT at $50^{\circ} \mathrm{C}$ for $30 \mathrm{~min}$ followed by initial denaturation at $94^{\circ} \mathrm{C}$ for $2 \mathrm{~min}, 40$ cycles of denaturation at $94^{\circ} \mathrm{C}$ for $30 \mathrm{sec}$, annealing at $55^{\circ} \mathrm{C}$ for $30 \mathrm{sec}$, extension at $72^{\circ} \mathrm{C}$ for $1 \mathrm{~min}$, and final extension at $72^{\circ} \mathrm{C}$ for $1 \mathrm{~min}$. The amplified cDNA was analyzed by electrophoresis on $1.5 \%$ agarose gel.

The rRT-PCR was performed in AB 7500 Fast real time PCR machine (Applied Biosystems, USA) using AgPath-ID ${ }^{\mathrm{TM}}$ One Step RT-PCR Kit (Life Technologies, USA) as recommended by the manufacturer. The reaction was performed in $25 \mu \mathrm{L}$ volumes in $0.1 \mathrm{~mL}$ MicroAmp Fast PCR 8-tube strips; $5 \mu \mathrm{L}$ RNA templates were added to $20 \mu \mathrm{L}$ reaction mix. The thermal profile used by Wise et al. (2004) was modified as shown in Table 2 considering the requirements of the present kit and the real-time PCR machine.

Table 2. The original and modified thermal profile of rRT-PCR for the detection of Matrix (M) gene of NDV

\begin{tabular}{l|c|c}
\hline & $\begin{array}{c}\text { Original thermal profile } \\
\text { (Wise } \text { et al., 2004) }\end{array}$ & $\begin{array}{c}\text { Modified thermal } \\
\text { profile }\end{array}$ \\
\hline $\begin{array}{l}\text { Reverse transcription } \\
\text { Initial denaturation }\end{array}$ & $50^{\circ} \mathrm{C}$ for $30 \mathrm{~min}$ & $45^{\circ} \mathrm{C}$ for $10 \mathrm{~min}$ \\
\hline 40 cycles of PCR & $94^{\circ} \mathrm{C}$ for $15 \mathrm{~min}$ & $95^{\circ} \mathrm{C}$ for $10 \mathrm{~min}$ \\
Denaturation & & \\
Annealing & $94^{\circ} \mathrm{C}$ for $10 \mathrm{sec}$ & $94^{\circ} \mathrm{C}$ for $15 \mathrm{sec}$ \\
Extension & $52^{\circ} \mathrm{C}$ for $30 \mathrm{sec}$ & $60^{\circ} \mathrm{C}$ for $30 \mathrm{sec}^{*}$ \\
\hline
\end{tabular}

* Signals were collected at this cycle

Comparison of the sensitivity of real time and conventional RT-PCR

To compare the sensitivity of conventional and real-time RT-PCR, RNA extracted from a selected sample was serially diluted 10-fold from undiluted to $10^{-9}$. All the dilutions were tested in conventional and real time RT-PCR. The highest dilution at which the test gave positive result was considered as the detection limit.

\section{Results and Discussion}

All the seven reference isolates of NDV retested by conventional RT-PCR were positive for NDV F gene. A 535 bp product was amplified (Fig. 1a).

The initial trials of rRT-PCR using the thermal profile described by Wise et al. (2004) were not successful. However, after some modification of the thermal profile all the seven isolates were successfully amplified (Fig. 1b). In the modified thermal profile 
the annealing and extension steps were combined to a single step at $60^{\circ} \mathrm{C}$ for $30 \mathrm{sec}$. This was needed as a different real-time PCR machine was used in the present study. The temperature and time for reverse transcription and initial denaturation were also modified as suggested by the manufacturer of the RT-PCR kit used in the present study. The $\mathrm{C}_{\mathrm{T}}$ values for the seven reference isolates were 15.98, 32.34, 32.68, 25.89, 32.60, 17.92 and 22.72. Typical amplification curve was observed with four out of seven samples. Two samples having very good $C_{T}$ values (15.98 and 17.92) did not show good exponential rise in the curve. Another sample also having good $\mathrm{C}_{\mathrm{T}}$ value (25.89) did not show typical curve. The reason for this atypical curve needs to be investigated further. Inadequate mixing of reagents could result in such atypical curves.

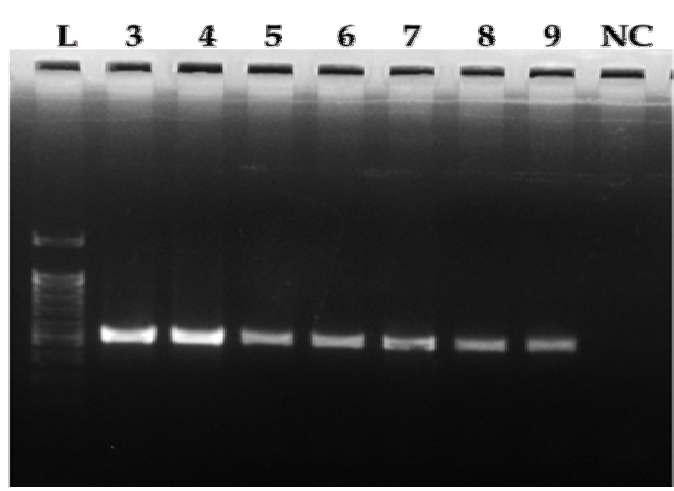

Fig. 1a. Amplification of $535 \mathrm{bp}$ fragment of $\mathrm{F}$ gene from NDV isolates by conventional RT-PCR

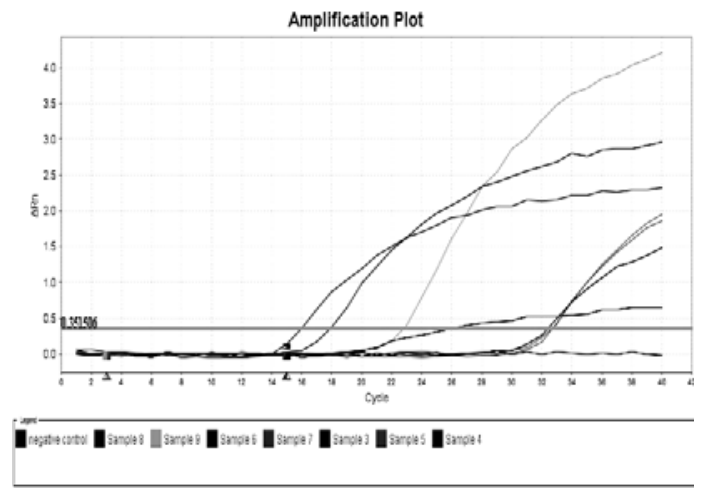

Fig. 1b. Amplification plot (linear view) of rRT-PCR for $\mathrm{M}$ gene for seven NDV samples

( $\mathrm{L}=$ DNA ladder, 3-9 = Samples with ID \# 3-9)

Wise et al. (2004) developed three protocols for NDV rRT-PCR, two for M gene and one for $\mathrm{F}$ gene. The present protocol is one of these three protocols, which was based on the conserved region of M gene and was able to detect NDV strains of lentogenic, mesogenic and velogenic pathotypes. This protocol is considered as USDA-validated protocol. However, it has been recently demonstrated that within class II APMV-1 viruses, the matrix gene is not highly conserved and false negatives occurred in outbreak investigations or routine surveillance in poultry using the USDA-validated real-time RT-PCR assay targeting this gene (Cattoli et al., 2009; Khan et al., 2010). To overcome this problem, Khan et al. (2010) modified the probe of Wise et al. (2004) by including three degenerate bases in the probe. In the present study the primers of Wise et al. (2004) and the modified probe of Khan et al. (2010) were used.

To compare the sensitivity of conventional RT-PCR for F gene fragment and rRT-PCR for M gene fragment, 10-fold serial dilutions of RNA of one selected isolate (isolate \#9) were tested by both these methods. On conventional RT-PCR a clear and distinct band of RT-PCR product of 535bp was observed in undiluted, $10^{-1}$ and $10^{-2}$ dilutions of RNA (Fig. 2a). cDNA band was hardly visible in the next two dilutions. However, in case of rRT-PCR the undiluted sample as well as the serial dilutions from $10^{-1}$ to $10^{-4}$ 
were positive with $C_{T}$ value ranging from 23.07 to 36.59 (Fig. 2b). Hence, the rRT-PCR appears to be 100-fold more sensitive than the conventional RT-PCR. Very high sensitivity of rRT-PCR has been reported (Wise et al., 2004).

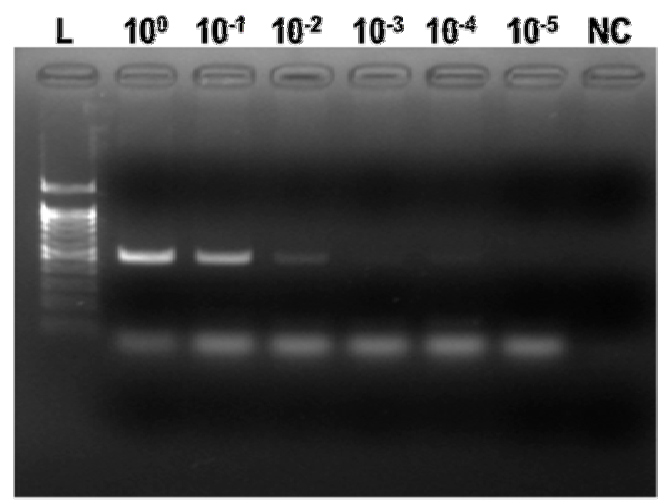

Fig. 2a. Amplification of $535 \mathrm{bp}$ fragment of $\mathrm{F}$ gene by conventional RT-PCR from the undiluted and 10 -fold serial dilutions of RNA of NDV Isolate \# 9

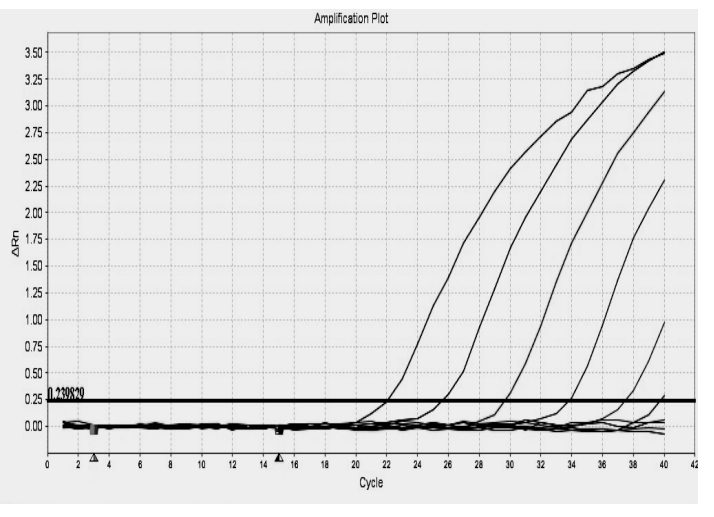

Fig. 2b. Amplification of matrix gene of NDV by rRT-PCR from the undiluted and 10-fold serial dilutions of the Isolate \# 9

Newcastle disease is endemic in Bangladesh. With the emergence of highly pathogenic and low pathogenic avian influenza, differential diagnosis between NDV and avian influenza is often required because of the clinical and pathological similarity. This is the first report of the application of rRT-PCR for the detection of NDV in Bangladesh. Availability of this modern, sensitive and quick diagnostic tool will be very useful in confirmation or ruling out NDV from suspected avian influenza outbreaks. This test will be useful for initial screening of samples in NDV surveillance.

\section{References}

Barman LR 2016: Molecular and pathogenic characterization of Newcastle disease virus circulating in Bangladesh. PhD dissertation. Department of Pathology, Bangladesh Agricultural University, Mymensingh.

Barman LR, Islam MN, Flensburg MF, Permin A, Petersen SL, Islam MR 2010: Newcastle disease vaccination regimen comprising both lentogenic and mesogenic strains is more effective than Lentogenic strain only. The Bangladesh Veterinarian 27 1-7.

Cattoli G, De Battisti C, Marciano S, Ormelli S, Monne I, Terregino C, Capua I 2009: Falsenegative results of a validated real-time PCR protocol for diagnosis of Newcastle disease due to genetic variability of the matrix gene. Journal of Clinical Microbiology 47 3791-3792.

Chowdhury TIMFR, Sarker AJ, Amin MM, Hossain WIMA 1981: Studies of Newcastle disease in Bangladesh. Bangladesh Veterinary Journal 15 1-9. 
Farkas T, Szekely E, Belak S, Kiss I 2009: Real-time PCR-based pathotyping of Newcastle disease virus by use of TaqMan minor groove binder probes. Journal of Clinical Microbiology 47 2114-2123.

Islam MA, Haque MH, Hossain MT, Islam MT, Zinnah MA, Khan MSR 2010: Isolation and detection of Newcastle disease virus from field outbreaks in broiler and layer chickens by reverse transcription-polymerase chain reaction. Journal of Veterinary Medicine 8 87-92.

Jestin V, Jestin A 1991: Detection of Newcastle disease virus RNA in infected allantoic fluids by in vitro enzymatic amplification (PCR). Archives of Virology 118 151-161.

Khan MFR, Ahmed S, Hossen ML, Imran MA, Nazir KHMNH, Rahman M, Rahman MT, Rahman MB 2014: Isolation, molecular detection and BHK-21 adaptation of Newcastle disease virus of field cases in layer farms of Bangladesh. Scientific Journal of Microbiology 3 66-73.

Khan TA, Rue CA, Rehmani SF, Ahmed A, Wasilenko JA, Miller PJ, Afonso CL 2010: Phylogenetic and biological characterization of Newcastle disease virus isolates from Pakistan. Journal of Clinical Microbiology 48 1892-1894.

Kho CL, Azmi ML, Arshad SS, Yusoff K 2000: Performance of an RT-nested PCR ELISA for detection of Newcastle disease virus. Journal of Virological Methods 86 71-83.

Lamb RA, Collins PL, Kolakofsky D, Melero JA, Nagai Y, Oldstone MBA, Pringle CR, Rima BK 2005: Family Paramyxoviridae. In: Fauquet CM, Mayo MA, Maniloff J, Desselberger U, Ball LA (eds.): Virus Taxonomy, VIIIth Report of the International Committee on Taxonomy of Viruses. Elsevier Academic Press, San Diego pp. 655-668.

Mazumder AC, Khatun S, Nooruzzaman M, Chowdhury EH, Das PM, Islam MR 2012: Isolation and identification of Newcastle disease viruses from field outbreaks in chickens and pigeons. The Bangladesh Veterinarian 29 41-48.

Noor M, Rajib DMM, Chowdhury EH, Islam MR, Das PM 2005: Pathogenic characterization of Newcastle disease virus field isolates. Progressive Agriculture, 16 91-98.

Nooruzzaman M, Mazumder AC, Khatun S, Chowdhury EH, Das PM, Islam MR 2015: Pathotypic and genotypic characterization of two Bangladeshi isolates of Newcastle disease virus of chicken and pigeon origin. Transboundary and Emerging Diseases 62 102-107.

OIE 2012: Newcastle disease. Manual of diagnostic tests and vaccines for terrestrial animals. Chapter2.3.14.http:// www.oie.int/ international-standard-setting/ terrestrial- manual/access-online.

Pham HM, Konnai S, Usui T, Chang KS, Murata S, Mase M, Ohashi K, Onuma M 2005: Rapid detection and differentiation of Newcastle disease virus by real-time PCR with melting-curve analysis. Archives of Virology 150 2429-2438

Qiu X, Yu Y, Yu S, Zhan Y, Wei N, Song C, Sun Y, Tan L, Ding C 2014: Development of strand-specific Real-Time RT-PCR to distinguish viral RNAs during Newcastle disease virus infection. The Scientific World Journal, Article ID 934851 01-10. 
Saha S, Islam MA, Rahman MM, Alam KMT 1997: Biological characters of the field isolates of Newcastle disease virus. Bangladesh Veterinary Journal 31 123-125.

Tan SW, Omar AR, Aini I, Yusoff K, Tan WS 2004: Detection of Newcastle disease virus using a SYBR Green I real time polymerase chain reaction. Acta Virologica 48 23-28.

Wang Z, Liu H, Xu J, Bao J, Zheng D, Sun C, Wei R, Song C, Chen J 2006: Genotyping of Newcastle disease viruses isolated from 2002 to 2004 in China. Annals of the New York Academy of Sciences 1081 228-239.

Wise MG, Suarez DL, Seal BS, Pedersen JC, Senne DA, King DJ, Kapczynski DR, Spackman E 2004: Development of a real-time reverse- transcription PCR for detection of Newcastle disease virus RNA in clinical samples. Journal of Clinical Microbiology 42 329-338.

Zhang L, Pan Z, Geng S, Chen X, Hu S, Liu H, Wu Y, Jiao X, Liu X 2010: Sensitive seminested RT-PCR amplification of fusion gene sequences for the rapid detection and differentiation of Newcastle disease virus. Research in Veterinary Science 89 282-289. 